\title{
Sustainable Tourism Model in Pagilaran Tea Plantation Agrotourism, in Indonesia
}

\author{
Raras Gistha Rosardi ${ }^{*}$, Sucihatiningsih Dian Wisika Prajanti ${ }^{2}$, Hamdan Tri Atmaja $^{3}$ Juhadi $^{4}$ \\ ${ }^{1}$ Doctoral Program in Social Science Education of Postgraduate, Semarang State University, Semarang 50237, Indonesia \\ ${ }^{2}$ Development Economics Study Program, Semarang State University, Semarang 50237, Indonesia \\ ${ }^{3}$ History Education Study Program, Semarang State University, Semarang 50237, Indonesia \\ ${ }^{4}$ Geography Education Study Program, Semarang State University, Semarang 50237, Indonesia
}

Corresponding Author Email: rarasgistha@students.unnes.ac.id

https://doi.org/10.18280/ijsdp.160519

Received: 22 July 2021

Accepted: 7 September 2021

\section{Keywords:}

agrotourism, sustainable tourism, tea plantations

\begin{abstract}
Sustainable development is a global agenda with issues of economic growth, environment, and welfare. The instrument for realizing sustainable development is through sustainable tourism. Agrotourism as an effort to apply the principles of sustainable tourism focusing on environmental, social, and economic dimensions. This study aims to find a sustainable tourism model in Pagilaran Tea Plantation Agrotourism. This study uses a qualitative method with a case study concept. The data collection techniques used in the study were observation, indepth interviews, literature study, and documentation. The data were analyzed by source triangulation and the data were analyzed with the help of Atlas.ti.8 software. The result of this study was the model of sustainable tourism in Pagilaran Tea Plantation Agrotourism that involves social, economic, ecological, cultural, and educational dimensions. The novelty of this study is that the Sustainable Tourism model in Pagilaran Tea Plantation Agrotourism involves the University element and is committed to upholding the principles of Tri Dharma of Higher Education, namely Education, Research, and Community Service. Pagilaran Tea Plantation Agrotourism implements Pentahelix collaboration in realizing sustainable tourism by involving academics, companies, communities, government, and media. Pagilaran Tea Plantation Agrotourism is committed to being a vehicle for family tourism, the official tourism, and study tour by prioritizing edutourism and providing ecological insight. The tourism potentials such as Tea walking, Tea Factory, and tea picking dance become the uniqueness and attraction of Pagilaran Tea Plantation Agrotourism. The novelty result of this study is that the Educational dimension is an element that can strengthen the realization of Sustainable Tourism.
\end{abstract}

\section{INTRODUCTION}

At the 19th plenary meeting, on 14th June 1992, the Conference adopted the Rio Declaration on Environment and Development, Agenda 21, and a statement of principles for the Global Consensus on Management, Conservation, and Sustainable Development [1]. Sustainable Development is the agenda of countries in the world [2]. The issue of development based on conservation principles is a global agenda. Environment and development must walk in harmony. After the Earth Summit (High-Level Conference), the agenda was continued with the MDG's (Millennium Development Goals) and SDG's (Sustainable Development Goals). In 2015, the United Nations launched seventeen Sustainable Development Goals (SDGs) providing a new system of indicators for sustainable development for the application with all industrial sectors in all countries [3]. Thus, based on the conference agreement affirmed that the industrial sector must be based on sustainable development for long-term welfare.

The United Nations (UN) represented by 189 countries declared the Millennium Development Goals (MDG's) with the framework of fighting poverty in multiple dimensions [4]. The main issue in the MDGs is poverty. In an effort to find solutions to the problem of poverty, policies, strategies, and development strategies are based on strategies of pro-growth, pro-jobs, pro-poor, and pro-environment [5]. The Future We Want document is one of the indicators for the success of the MDGs produced at the Rio conference on 20th June 2012 or known as the Earth Summit (High-Level Conference) which shows the commitment of the nations in the world to conduct a development with a green economy paradigm [6]. The development with a green paradigm is assumed that in carrying out the development process, it is necessary to involve the ecological dimension so that sustainability is achieved. The existence of a human-nature-building relationship as life support [7]. The principle of development by conserving nature will always be the reference of the global agenda to conduct evaluation and agreements of countries in the world further which aims at prosperity and maintains the sustainability of the universe.

After the Earth Summit (High-Level Conference) agenda, the MDG's are then continued with the SDG's until 2030. Sustainable development includes three aspects, namely aspects of economic development, social development, and environmental protection [2]. The three aspects must work together so that the pillars of development can be realized. Sustainable Development Goals (SDG's) are expected to be able to bring prosperity, equity, and sustainability [8]. 
Economic, social, and environmental Sustainable Development are important factors and cannot be ignored. SDG's pillars need to be internalized through policies in the public sector. Economic development without considering the dimension of sustainability will result in new problems. For example, infrastructure development without considering AMDAL (Environmental Impact Analysis) will impact the emergence of environmental problems and natural disasters.

An environmentalist said that environmental problem is a moral issue [9]. Earth systems are under intense stress on biological, chemical, and geological cycles, resulting from human-caused use of resources and overuse [10]. Human behavior affects the use and utilization of natural resources. Environmental problems are caused by human factors as actors in the use of natural resources. Thus, environmental damage can be prevented and reduced by education.

Environmental issues and efforts to improve welfare and equitable distribution of prosperity can be carried out by optimizing the agrarian sector. As a country with abundant natural resources, fertile soil, and a favorable climate, the agricultural sector always needed to be a priority. In developed countries, agriculture has long been no longer considered as the main economic sector and its role as a contributor to national economic growth is often underestimated or ignored [11]. In fact, Indonesia is one of the few countries that have been bestowed the luxury of natural resources [12]. Indonesia is an agrarian country and its agriculture sector is considered to play important role in regional economic development [13]. The sector that has become the identity of the country with abundant natural resources is plantations. The plantation is an Indonesian asset and state investment that needs to be preserved and get a policy priority.

One of the biggest assets of Plantation in Indonesia is Tea Plantation. The plantation sector such as tea has been playing an important role in the rural economy [14]. Plantations can provide livelihoods for the wide community, especially rural communities who have so far depended on their source of income from crops in plantations. Moreover, Indonesian natives should be proud that Indonesia is the 7th largest tea producer in the world [15]. Another privilege of plantations is that plantations are a labor-intensive sector. A large workforce can be absorbed in the plantation sector from various educational backgrounds and various labor classifications. The plantation is an effective strategy to break the unemployment rate. So far, plantations have only been used for production and distribution activities. Indonesia has a variety of plantations that become superior commodities including tea, coffee, oil palm, and rubber plantations. Indonesia is one of the countries that has extraordinary natural blessings and is not necessarily owned by other countries, even in Asia [12]. The predicate as an agrarian country must be maintained for the strength and sovereignty of the Indonesian state.

The study of plantations involves structural and cultural aspects, even though plantations are an "unsexy issue". The issue of plantations still holds the pockets of conservation, poverty, and still leaves politics and unfinished agrarian laws [16]. Whereas plantations have a major contribution to national income, especially to the Land and Building Tax. Indonesia has a large plantation area that produces exportvalue commodities such as tea and coffee. According to Gunadi [12], tea is an extraordinary resource. However, it is difficult to overcome the problem of tea commodity in
Indonesia, because it is considered small and underappreciated.

Attention to plantations needs to be carried out seriously by paying attention to activities that utilize plantation land that can bring multiplier effects. Plantation land-use activities other than production activities are nature-based tourism. Because talking about plantation issues is not only about planting activities but more broadly related to the social role, the role of civilization, and the role of the environment [16]. These three roles can be realized through the strategy of using plantation land for tourism activities. Tourism relevant to plantation land use is agrotourism [17]. Tourism in the plantation environment has not yet received the attention of the government and the response of the community is still minimal. Agrotourism is expected to be able to liven up the plantations.

Tourism is seen as a strategic instrument to realize sustainable development goals [18]. Tourism can collaborate on economic, ecological, and social dimensions. The sector that can be expected to improve the local community's economy is tourism especially nature-based tourism which can provide conservation values and community social dynamics experiences change due to tourism activities that grow and strive to always carry out innovation. The tourism potential in Indonesia can be proud of the increase in the positive trend of foreign tourist visits to Indonesia through all entrances in October 2019 amounted to $\mathbf{1 , 3 5 4 , 3 9 6}$ visits or an increase of $4.86 \%$ compared to the same period in October 2018 which totaled $\mathbf{1 , 2 9 1 , 6 0 5}$ visits [19]. Tourism's contribution to National GDP (Gross Domectic Product) is $8 \%$ and foreign exchange earnings of 240 trillion [19]. Tourism can be used as a catalyst for development, in addition to accelerating the distribution of income, increasing employment opportunities, increasing tax revenues, increasing national income, as well as being able to strengthen the balance of payments position [20]. However, in fact, tourism is still a sector that has not received the main attention of many parties. Equitable distribution of tourism development in all regions of Indonesia is needed so that tourism activities provide benefits other than economic, social, cultural, and educational benefits.

Research on tea plantations is still dominant related to the cultivation of tea plants and related to the impact of pesticide use. However, research on the existence and potential of agrotourism in a tea plantation is still minimal and the novelty produced has not been seen. This article would conduct a research study on the Pagilaran Tea Plantation which has a business field, namely Agrotourism which has been going on since 2005. The Pagilaran Tea Plantation is a heritage plantation during the Dutch and British colonial times, then by the Dutch government, it was handed over to the Indonesian government in the era of President Soekarno's leadership. Later, by the Minister of Agriculture in that era, it was handed over to Gadjah Mada University to be managed as Research and Education as one of the forms of the Tri Dharma of Higher Education. The Pagilaran Tea Plantation covers an area of 1,113 hectares. Agrotourism is expected to be useful for the environment [21]. However, the Indonesian people have not fully realized the function of Agrotourism as a means of education so that the use of Tea Plantation Agrotourism has not touched holistically the aspects of education and sustainability values. Based on this background, this research is a model of sustainable tourism in Pagilaran Tea Plantation Agrotourism, Indonesia. 


\section{LITERATURE REVIEW}

\subsection{Sustainable tourism}

Tourism is a multidisciplinary study that can be seen from various fields of science [22]. Tourism can be studied from the perspective of the social sciences because it relates to human activities and their environment. Tourism is a complex activity, which can be considered as a big system and has various components such as economic, ecological, political, social, cultural components and so on [23]. In this theory, tourism has a big role to be able to change aspects of human life with all its activities and problems. Scientific studies about tourism refer to research on tourism, leading to four approaches to tourism, namely Advocacy, Adaptancy, Developmental, and Knowledge-Based. Knowledge Based stated that tourism is a multidisciplinary research field and tends to apply theories and methods from various fields related to tourism [24]. Tourism activities are carried out by people of various ages and social strata. All have the right to tourism activities because they have various purposes. This statement is supported by "People's perceptions of tourism destinations have been shown to play an important role in tourist decision-making, as perceptions and the image of preferred destinations positively influence tourist destination choices [25-28]". People will choose a tourist destination to go to based on their perception, of course, that perception is supported by the experience and image of the tourist destination. Therefore, maintaining the image of a tourism destination has an important role. Tourism is not just a temporary visit, but the hope is that it is sustainable. Given that tourism has many goals, namely relaxation, adding insight, developing knowledge, and exploring certain values according to the culture of the tourism object.

The United Nations Commission on Sustainable Development states that the principles of sustainable tourism management are: 1) Ensuring equal, effective, and active participation from all stakeholders, 2) Ensuring the participation of local residents who say yes or no in community, land, and regional development activities, and 3) Raising local people's mechanisms for control and maintenance of resources [29]. Conceptually defines sustainable tourism as "the development of tourism activities with an appropriate balance between the environmental, economic, and socio-cultural aspects to ensure long-term sustainability" [30].

Tourism development must pay attention to sustainable development aimed at sustainably increasing tourist satisfaction [31]. The definition of sustainable development includes among others: appropriate resource management. This has brought ecotourism to the forefront of sustainable tourism following the impact of conservation and development [32]. Sustainable tourism and ecotourism should not be considered as synonymous concepts in such a way that many forms of ecotourism may not be sustainable. For ecotourism to support sustainable development, which brings economic benefits while promoting nature conservation must go through careful planning and management [33].

Sustainable tourism activities mainly cover environmental, economic, social, and cultural aspects. Figure 1 illustrates this concept, the four aspects of sustainability for tourism. Due to natural resources have the potential to be intensively exploited in the tourism business, tourism activities will sometimes have a large impact on the environment, ecosystem, economy, society, and culture. Potential environmental impacts are broad ranging from global marine pollution to local disturbances in threatened areas extinction of plant and animal species in protected areas [34]. Therefore, a holistic balance between these four dimensions should be considered to ensure short-term and long-term sustainable development for the tourism sector in facing climate change. The principles of sustainable development should apply to various types of tourism activities and operations by building long-term and short-term strategies and programs. Research on sustainable tourism has been widely carried out [8, 35-40]. Previous research looks at approaches to tourism strategy, tourism impact, and agreement on the principles of sustainable tourism development, analysis of sustainable development in the tourism industry, measurement, and agribusiness performance models.

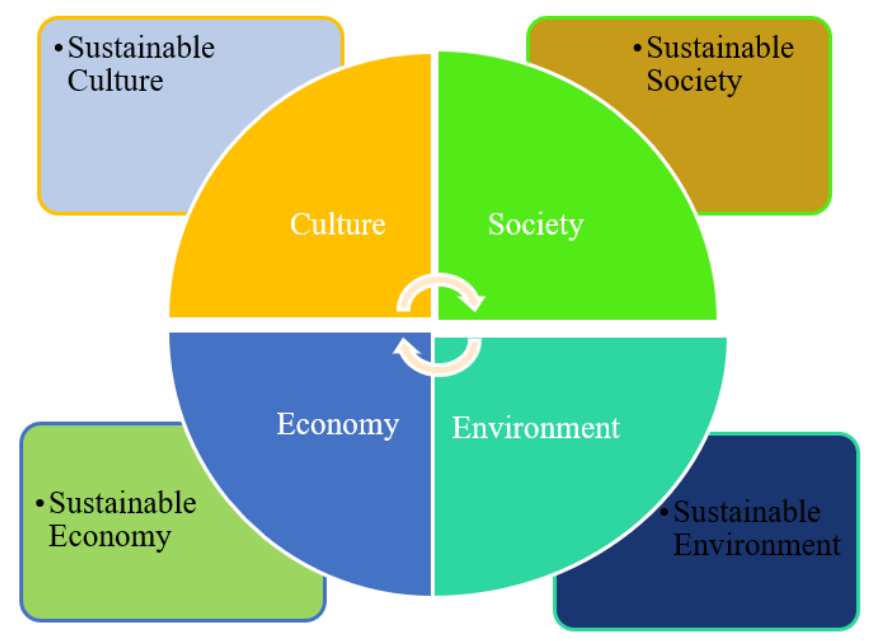

Figure 1. Four conceptual aspects required for achieving sustainable tourism source [30]

\subsection{Agrotourism}

One of the peculiarities of the leading tourist attraction in Indonesia is Agrotourism. This is because the Indonesian state has the potential for fertile land with abundant natural resources and superior agricultural products.

Agrotourism or agricultural tourism is defined as a series of tourism activities that utilize a location or agricultural sector from the beginning of production to acquired agricultural products in various systems and scales intending to expand knowledge, understanding, experience, and recreation in the agriculture field. Based on the research results stated that Agrotourism is a tool that has been widely used all over the world to intensify the socioeconomic aspects of local communities [17]. The qualitative study concludes that agrotourism can be a driver for the sustainable development of communities. The benefits include improving their social empowerment system, strengthening their social ties and developing their social skills and relationships, increasing the income of local people, diversifying products and intensifying economic activities, providing job opportunities, and alleviating poverty [41]. The development of agrotourism has a positive and significant effect on the welfare of the community [42].

If the management of agrotourism is carried out with sustainable principles, then tourism, besides becoming a catalyst for development, can also be a conservation investment for future generations. Agrotourism that is presented with sustainable tourism management can bring 
changes to the paradigm of the community in traveling. Sustainable tourism can reconcile tensions and balance various aspects of heritage conservation, tourism management, social pressures, and economic development [43]. Agrotourism has the potential to increase awareness selected by the community about sustainable development [41]. Agrotourism management that is based on sustainable development and tourism will be able to become an innovation in realizing tourism goals that empower the community in an effort to improve their welfare. In addition, conservation elements will not be abandoned through Agrotourism guided by the principle of tourism in Indonesia, namely Sapta Pesona Wisata which consists of elements: Safe, Orderly, Clean, Cool, Beautiful, Friendly, and Memories.

\section{METHOD}

\subsection{Study setting}

This research was conducted at the Pagilaran Tea Plantation, Pagilaran Hamlet, Keteleng Village, Blado District, Batang Regency. Coordinates -6.924062, 109.721326. The uniqueness of this research location is that Pagilaran has potential in the agricultural sector, namely in particular tea plantations. The commodity of tea is the pulse of the economy for most residents of Keteleng Village, Blado District, Batang Regency. Whereas Batang Regency itself, which incidentally has an area of 78,864.16 hectares, relies on the fishery sector because it is located along the north coast.

Batang Regency, Central Java, has a topography of highlands, lowlands, and coastal areas. With a fairly complete natural appearance, Batang Regency has tourism potential and a center for scientific studies that can be used for regional development and human resource development. In the highlands of Batang Regency, there is a large area of land that is planted with one world commodity, namely tea. Pagilaran Tea Plantation is located in Pagilaran Hamlet, Keteleng Village, Blado District, Batang Regency, Central Java. With an area of 1,130 hectares of Pagilaran Tea Gardens, it is located above an altitude of 600-1600 meters above sea level. The Pagilaran plantation is divided into three afdeling based on the height and type of tea, namely Afedeling Pagilaran, Andongsili Afdeling, and Afdeling Kayulandak (Figure 2).

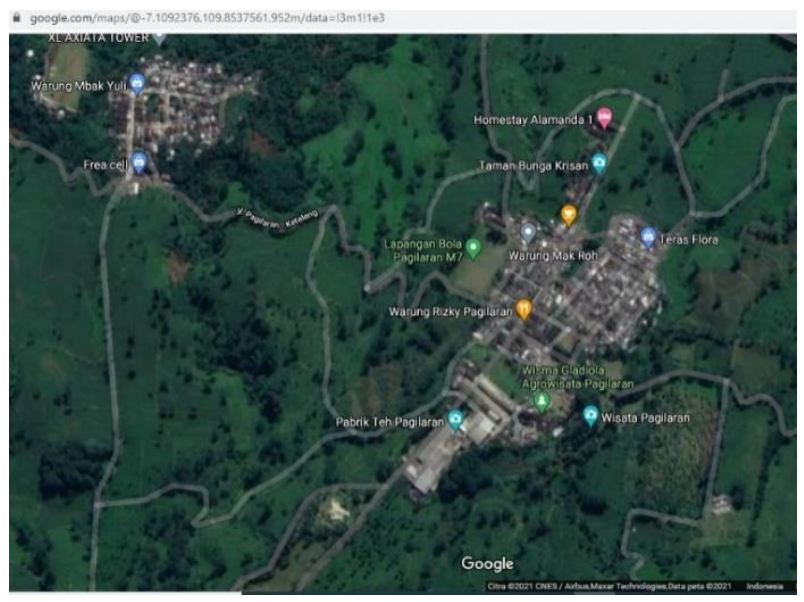

Figure 2. Map of Pagilaran tea plantation

Based on the administrative map of Batang Regency obtained from the Office of Bappeda, Pagilaran Tea Plantation is bordered by the boundaries of the Pagilaran Agrotourism Area which is to the south of Keteleng Village, to the north of Kalisari Village, to the east of Ngadirejo Village, and the west of Kembanglangit Village. For the area of the Pagilaran Agrotourism Area, Bappeda uses the reference from the Book of Documents for the Pagilaran Strategic Area Tourism Development, 2016 which is 34 hectares (Figure 3).

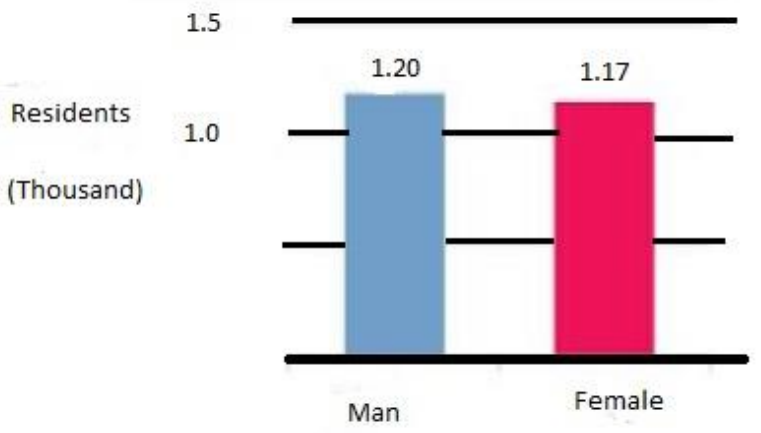

Figure 3. Total population of Keteleng Village, Blado District, Batang Regency in 2020

This study was qualitative research with a Case Study method. This was due to this study focused on events based on human understanding and behavior based on human opinions [44] The subjects in this study could be individuals, groups, institutions, or society. A case study is a process of seeking knowledge to investigate and examine phenomena that occur in real life. In this article, the research was conducted to find a management model of Pagilaran Tea Plantation Agrotourism.

The informant selection technique used purposive sampling. The researchers conduct in-depth interviews with 6 key Persons. In addition, they also conducted in-depth observations at Pagilaran Tea Plantation, Keteleng Village, Pagilaran Hamlet, Blado District, Batang Regency, Central Java. The analysis technique used was an interactive analysis technique with the validity of data triangulation of data or sources. The analysis of the findings of this study used Atlas.ti software.

\section{ANALYSIS AND FINDING}

PT. Pagilaran is a company that focuses on plantation, trading, consulting, and agro-tourism. The core business of Pagilaran is tea plantations which have 2 core plantations and four plasma plantations. Pagilaran Company is committed to and plays a role in increasing its positive contribution to society in line with its business growth. Pagilaran Tea Plantation in its management is different from other plantations because it is under the management of a university with the principle of Tri Dharma of Higher Education. The following is information on the history of the establishment of Pagilaran Company.

Pagilaran Company became one of the tea companies in Indonesia starting in 1840 , a Dutch citizen named E. Blink opened forest land in the Pagilaran area then planted it with quinine and coffee. It turns out that the results obtained were not pleasing. For that, in 1899, it was replaced with tea plants. However, the result of quinine and coffee cultivation was not good because of natural conditions and the land has turned to the cultivation of tea plants.

In its development, the plantation was taken over by the 
Dutch who were colonizing Indonesia at that time. Under Dutch rule, tea plantations experienced rapid development. This was evidenced by the addition of plantation areas by auctioning the surrounding land.

In 1920, the tea plantation experienced a fire so the business and activities came to a complete halt. Finally, in 1922, the tea plantation was bought by the British who later carried out repairs. In 1928, by the British, the Pagilaran plantation was merged with P \& T Lands (Pemanukan and Tiiasem). During this merger period, the construction of tire cable facilities to facilitate the transportation of tea shoots from the garden to the tea processing factory began.

After that Britain lost to Japan in the "Great East Asian war", then the plantations were controlled by Japan and the plantations were replaced with food crops to meet the food needs of the Japanese army in World War II.

After Indonesia's independence from colonialism, in 1964, through the Decree of the Minister of PTIP, Prof. Ir. Toyib Hadiwijaya, the plantations were handed over to Gadjah Mada University to be used as a means of student education and research. Then, the company changed its name to PN (State Company) Pagilaran and handed over its management to the Faculty of Agriculture of Gadjah Mada University. With a land area of more than 1000 ha, the Faculty of Agriculture, Gadjah Mada University is trusted to manage it as a productive business entity and should not lose money. This led to the option to continue to manage it as a productive commercial asset and managed by Pagilaran Company.
Furthermore, Pagilaran plantations are managed with a vision and mission to support not only the Tri Dharma of education and research but also real service to the community of plantation businesses. Along with this process, the Faculty of Agriculture, Gadjah Mada University, through PT. Pagilaran also obtained another 208 ha of Cultivation Right in Segayung Utara, Batang Regency, Central Java to be later developed as cocoa plantations.

On January 1, 1974, the company's status was changed from PN Pagilaran to Perkebunan Perindustrian Perdagangan dan Konsultasi (Plantation, Industry, Trade and Consulting) Pagilaran Company. Pagilaran Company received an assignment from the Government to develop plantations with the PIR (Perkebunan Inti Rakyat/ People's Core Plantation) pattern from 1985/1986 until now with areas spreading over several provinces (Yogyakarta Special Region, Central Java, and East Java).

Starting on February 21, 1985, Pagilaran Company received a letter of assignment from the minister of Agriculture Prof. Sumantri Sastrosudiarjo No. KB.340/97/mentan/II/1985 to become a People's Core Plantation (PIR) of Central Java covering an area of 4700 ha spread across Batang, Banjarnegara, and Pakalongan regencies and supported by a decree from the Governor of the Head of the Level I Region of Central Java Number: 525/05/740 which supported successful development of agriculture in Central Java.

Currently, Pagilaran tea plantation is a big plantation in Indonesia.

Table 1. Area and tea production in large private plantations in central java province 2015-2017

\begin{tabular}{cccccc}
\hline No. & Area & Wide of Area (Ha) & Production (Ton) & Productivity (Kg/Ha) & Number of Labor Absorption (TK) \\
\hline 1. & Temanggung Regency & 22 & 27 & 1.209 & 222 \\
2. & Kendal Regency & 287 & 3 & 10 & 452 \\
3. & Wonosobo Regency & 769 & 2.023 & 3.034 & 1.170 \\
4. & Batang Regency & 1.113 & 2.125 & 2.306 & 1.475 \\
5. & Karanganyar Regency & 384 & 700 & 1.8248 & 588 \\
\hline
\end{tabular}

Source: Indonesian Plantation Statistics of Tea Commodity 2015-2017 [45]

Based on Table 1, it is proven that the tea plantations in Batang Regency, Central Java, namely Pagilaran Tea Plantation is the largest in Central Java, Indonesia. The uniqueness of Pagilaran Tea Plantation is in its management principles, Pagilaran Tea Plantation is committed to carrying out its activities based on the Tri Dharma of Higher Education, namely Education, Research, and Community Service. Evidence that the company of Pagilaran contributes to the Tri Dharma of Higher Education, namely Education, Research, and Community Service Programs that have been implemented.

Table 2. The Tri Dharma Programs of Higher Education have been implemented by PT. Pagilaran

\begin{tabular}{ccc}
\hline Research & Environmental Development & Hall Medicine \\
\hline 1.254 & 5 & 7 \\
\hline
\end{tabular}

The uniqueness of the Pagilaran Company is that the Pagilaran Tea Plantation is the only plantation under the University, because based on the history of the plantation journey that at that time the government gave trust to the Dean of the Faculty of Agriculture, Gadjah Mada University to be able to manage the plantation for scientific development and research. Table 2 shows the Company's commitment to realize the tri dharma of higher education. Pagilaran Company dedicates its mission to scientific development, improving community welfare and nature conservation. Research conducted in the Pagilaran tea plantation reached 1254 with researchers from students, lecturers, general researchers, government circles to take policy.

The statement from Informant $1(\mathrm{RG})$ said that:

"Plantation Management by Higher Education is the only one in Indonesia even in the world".

In Indonesia, State-owned plantations are managed by PTPN (Indonesian plantation company), which is a StateOwned Enterprise engaged in the management, processing, and marketing of plantation products. The cultivated commodities are coconut palm, rubber, sugar cane, tea, coffee, cocoa, tobacco, various wood, fruits, and various other plants. This is different from the Pagilaran tea plantation, where historically, the Government has given the authority to the UGM campus to manage the Pagilaran Tea Plantation with the HGU (Hak Guna Usaha/Cultivation Right) land status to be managed with the aim of conservation, education, and a research vehicle. This is the uniqueness and characteristic of Pagilaran Tea Plantation which has the principle of Tri Dharma of Higher Education (Education, Research and Community Service). The results of an interview with an informant named RG stated that:

"The management principle of Pagilaran Tea Plantation Company is the same as UGM, which is self-supporting so that 
PT involves alumni who have developed and have a position as CEO to contribute to developing Pagilaran both its plantations and agrotourism. The contribution of alumni can be in the form of share purchase".

The self-supporting here is the independence and initiative of the Pagilaran residents to be able to manage one of Pagilaran's core businesses, namely agrotourism and plantations. Pagilaran Tea Plantation can absorb up to 1,500 workers and all are local residents. Based on the statement from RG that Pagilaran is committed to the principle of "Clustered Closed Economy" and has become a BUMR (People's Owned Enterprise). The resources owned by Pagilaran can be managed by the local community and the involvement of alumni of PT Gadjah Mada University which already has a Company can join and become an investor and participate in developing Pagilaran Agrotourism. The establishment of the orderly area for street vendors is one of a program from PT. Pagilaran to develop agrotourism to be better and involve alumni who have become CEOs (Chief Executive Officer). The results of the interview conducted to RG (Informant 1) are as follows:

"The Board of Directors agreed that the management of Pagilaran with a Closed Cluster Economy model. This model is prioritizing Pagilaran natives to become part of PT. Pagilaran both as plantation workers and traders who support Agrotourism activities. In addition, tea production activities related to fertilizer suppliers, for example, prioritizing sourced from Pagilaran natives or their family relations so that the hope of increasing welfare will be realized".

Pagilaran has several business fields, namely plantation, trade, industry, and agrotourism. In this article, we focus on agrotourism with the utilization of natural expanses of tea plantations and full of knowledge as well as a tea factory industry that can be used as a means of education. Pagilaran agrotourism is managed with a collaborative system. Besides the managers of Agrotourism are employees of Pagilaran Company, it also certainly involves the Pokdarwis "Agrobinangkit" and the Department of Tourism, Youth, and Sports of Batang Regency as well as the Associations formed by the people of Pagilaran including the Association of Traders, cooperatives. Agrotourism can encourage various elements of society to move for Tourism for the common welfare activities.

The Pagilaran community collectively participates in developing Pagilaran as a Tourist area and has tourism awareness by participating as economic actors. PT. Pagilaran is committed that those who may participate in tourism activities are the native Pagilaran community, the outsiders from Pagilaran are prohibited to participate in tourism activities. The relevance of tourism activities in Pagilaran with community economic empowerment is based on the results of interview with SL (Informant 2) who stated that:

"Tourism must give economic value to the community, and the community is represented by the pokdarwis (Tourism Awareness Group)".

Figure 4 shows that tourism activities involve many elements, namely academics, government, community, economic actors, and media. This model supports the tourism theory that the management of tourism is based on the Pentahelix pattern (ABCGM), namely: Academic, Business, Community, Government, and Media. For the media itself related to the promotion of Pagilaran Agrotourism using the official website, namely https://agrowisata.pagilaran.co.id/ and social media Instagram which is akun jelajah pagilaran.

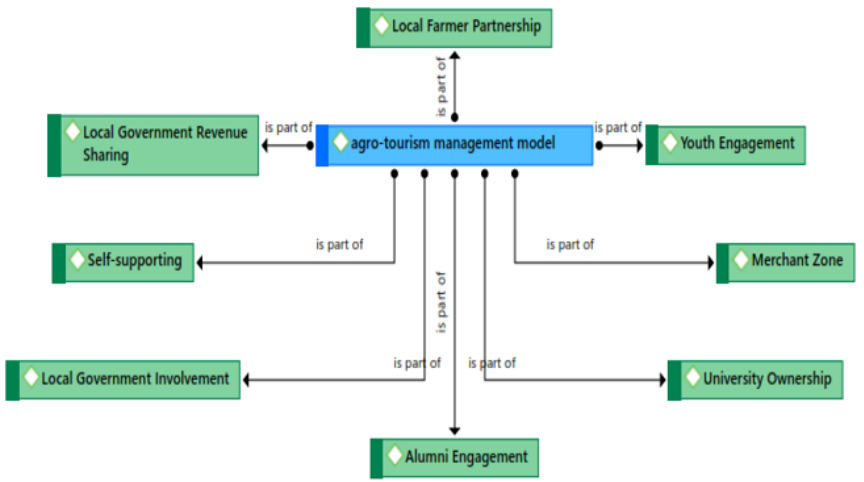

Figure 4. Agrotourism management model for Pagilaran tea plantation

In the management model, Pagilaran Tea Plantation Agrtourism is the only tourist attraction in Batang Regency, Central Java which also has a place to stay. The characteristics of tourist attractions which also have a place to stay, namely villas, guesthouses, and homestays in a cluster in the Pantura region and the surrounding area are only Pagilaran Agrotourism and Gucci which are located in Tegal Regency, Central Java. The two attractions have something in common, namely located on the slopes of mountains which presents natural beauty and coolness so that it is very relevant to be used as a reference for family tourism. Based on this classification, Pagilaran Tea Plantation Agrotourism only has a rival that is, Gucci Tourism Object which is quite far away, namely Tegal Regency, Central Java.

The statement from AW (informant 3) based on the results of the interview stated that:

"Pagilaran Agrotourism has no competitor when compared to tourist objects in Batang because only Pagilaran has integrated lodging with tourist attractions (R4)".

In this case, the management of Pagilaran Tea Plantation Agrotourism is more directed and focused on family tourism, officials tourism, and group tourism intending to increase knowledge, namely study tours. The following are the data visitors during 2019 before Covid 19 became a Pandemic in Indonesia

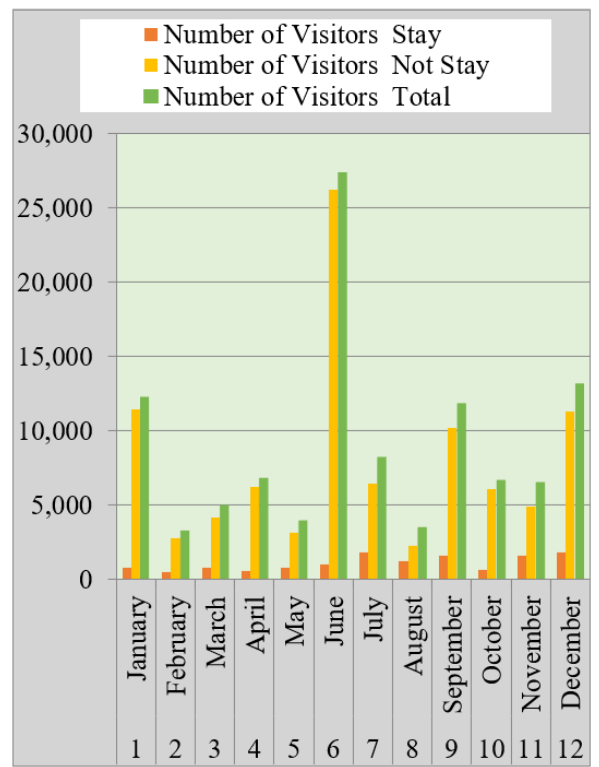

Figure 5. The number of visitors of Pagilaran agrotourism tourists during 2019 
In 2019, before the COVID 19 virus impacted tourism, namely early 2020 , the number of visits was relatively large and at the moment of the new school academic year holidays and new year's holidays in December and January the number of visitors increased significantly (Figure 5). Although the highest number of visitors was from the non-stay group, this did not reduce the enthusiasm of tourists to always visit Pagilaran Tea Plantation. The data on turnover or income obtained by PT. Pagilaran from the field of business, namely Agrotourism.

Table 3. The data on agrotourism financial turnover of Pagilaran Tea Plantation in 2019

\begin{tabular}{cccc}
\hline Year & Income & Expenditure & Profit \\
\hline 2019 & $2.241 .890 .655,30$ & $1.980 .851 .971,71$ & $261.038 .683,59$ \\
\hline
\end{tabular}

Table 3 shows the financial turnover data of the Pagilaran Tea Plantation agrotourism in 2019 which resulted in a profit of 261,038,683.59. In the current management of Tea Plantation Agrotourism, there is still no overall innovation in 16 years since its establishment in 2005 until now in 2021. Agrotourism is also experiencing a slowdown in responding to tourism currently favored by many people, but now it has emerged ODTW (Object of Attraction Tourism) in the form of a waterwheel selfie spot inspired by The Land of the Dutch Mill, tree houses, and hanging bridges. This could be because Pagilaran in managing the tourism business focuses on lodging, villas, guesthouses, and homestays as well as rental of meeting buildings and halls for official activities. The Batang Regency Offices are one of the visitors in groups who use the facilities of Agrotourism with overnight stays. Activities of Pagilaran Company which involves officials from Jakarta also uses Agrotourism facilities among them from the General Director of the Ministry of Tourism, the Chancellor of the Institute for Domestic Government. The houses used as official residences of the Director as well as to receive guests and several villas and emplacements belonging to Pagilaran Company is Dutch heritage buildings that once managed the Pagilaran Tea Plantation.

Besides Pagilaran offers lodging facilities, in the model of tourism management at the Pagilaran Tea Plantation, it also offers educational, research, and artistic activities. Education is realized through Teaching Factory tourism activities, namely visiting tea factories and seeing the process of tea production. In addition to the teaching factory, there is also a Tea Walking where in the morning it is offered to tourists in groups (study tour) who stay and see the sunrise and introduce the commodity of Pagilaran Tea to educate the wider community about tea.

The uniqueness of the Pagilaran agrotourism management model is that Pagilaran is committed to making Pagilaran Tea Plantation Agrotourism as an object for family tourism, officials tourism, and study tours. Based on the results of interviews with AN explained that:

"Agrotourism will focus on tourism that provides lodging facilities in groups and integrated tour packages with tea plantations including Tea Factory and Tea Walking and does not want to add other tourist attractions and other ODTW, which already exist so that it can run normally and want better control" (R6).

In contrast to other tourist attractions which are not controlled by lodging rules, the managers of Pagilaran Tea Plantation Agrotourism which has 4 homestays and 3 guesthouses with a capacity per homestay and a guesthouse between 10-13 people is committed that the lodging is indeed used for family tourism and officials tourism not a stay for tourists who break the rules, for example, no family ties (husband and wife). Pagilaran Tea Plantation Agrotourism is very keeping the lodging facilities owned are used for healthy and halal tourism so as to minimize the negative social impact that often occurs in tourism objects integrated with lodging.

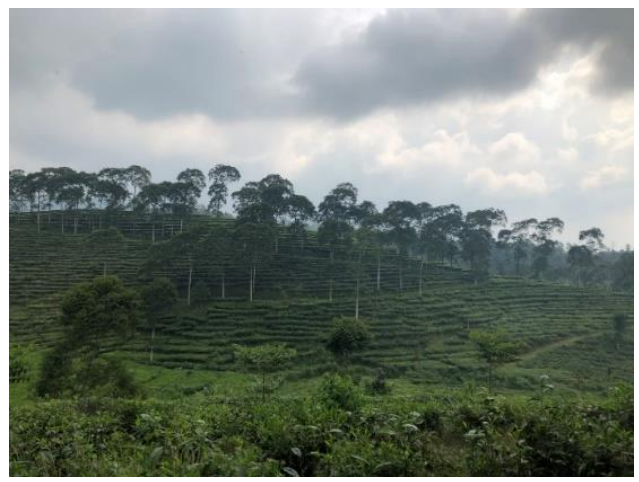

Figure 6. Pagilaran tea plantation spread

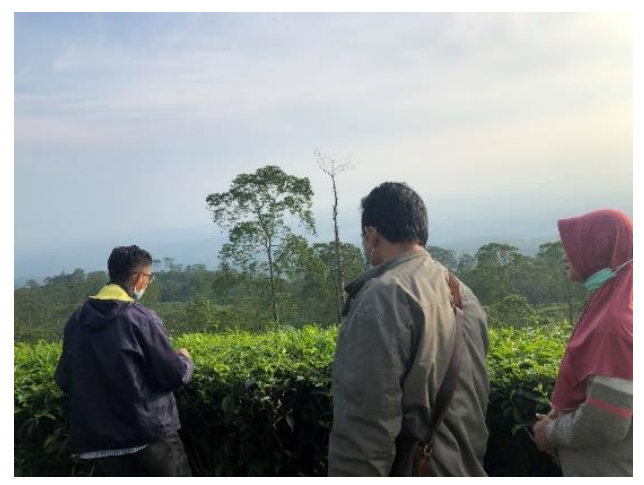

Figure 7. One of the educational activities regarding Pagilaran tea plant

Figure 6 shows the distribution of Pagilaran tea gardens, which are the advantages of natural tourism with green views and cool air. Figure 7 shows that Pagilaran provides educational services about tea plants to tourists so that agrotourism activities where there is an element of education can be implemented properly because they are guided by experts who understand tea plants.

The potential of Pagilaran Tea Plantation Agrotourism to become tourism that implements Sustainability is quite appropriate because Agrotourism has its own characteristics in terms of economic, environmental, social, and educational dimensions. The economic dimension that Pagilaran Agrotourism has an advantage with tea production with an expanse of plantation area of 1,113 hectares. The tea commodity produced by PT. Pagilaran has expanded with exports to foreign countries including countries in Europe, namely England, the Netherlands, Sweden, to the Middle East, namely Saudi Arabia, and to the United States. Figure 8. shows the Pagilaran agro-tourism sustainability scheme, namely economic, social, environmental and educational. The element of education that distinguishes it from other tourism models is because the educational element in the Pagilaran tea plantation agrotourism has the advantage that what is educated is something natural, namely tea plantations and the knowledge provided is based on research. 


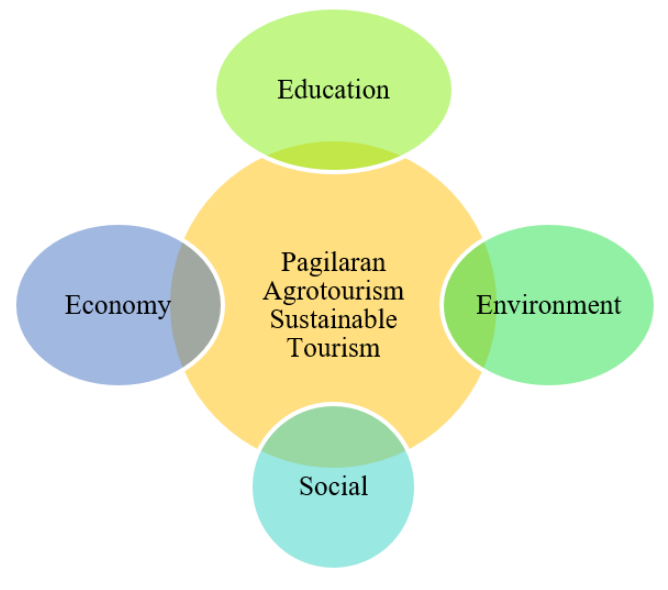

Figure 8. Pagilaran agrotourism sustainability tourism scheme

The environmental dimension that Tea Plantation is Rainforest Alliance certified by implementing the principles of Sustainable Agriculture i.e., Effective Management and Planning System, Conservation of Biodiversity, Conservation of Natural Resources, Livelihood Improvement and Community Welfare, and Sustainable Cattle Farm. In addition, the tagline of PT. Pagilaran, namely Wisdom and Natural Balance for Sustainability become the principles of tea plantation management integrated with tourism activities. In its development, Agrotourism once wanted to add tourist attractions in plantation areas, namely Paragliding sports tourism. Investors and the Tourism Office of Batang Regency have conducted a survey related to the implementation of the attraction to add to the advantages of the tourism packages in Pagilaran. However, the procedure for implementing Paragliding at the Tea Plantation is not easy because of the Board of Directors of Pagilaran Company is still considering the impact of the sport, which is the damage to the tea plant, so the plan has been postponed until now. In the environmental dimension, Pagilaran Company strictly implements fines for indiscriminate littering, prohibits hunting, polluting rivers, and burning garbage.

The economic dimension relies on tea production which is natively produced from the Pagilaran tea factory which is located within the plantation area. Among the teas that have been produced are black tea and green tea Sigma, White Tea, Yellow tea, Red Tea, Blue Shapire, and Red Ruby tea. In addition to tea production, PT. Pagilaran also owns a cocoa plantation located in North Segayung, Batang Regency, Central Java. All plantation products produced by PT. Pagilaran is in the office showroom of Pagilaran Agrotourism.

The social dimension of Pagilaran Tea Plantation is that Pagilaran Company in the Production Unit Pagilaran is a labor-intensive sector that can absorb up to 1,500 workers, including the Agrotourism unit. Socially, the existence of Pagilaran is the life expectancy of the indigenous Pagilaran people because it can break the chain of unemployment and poverty. Pagilaran Agrotourism provides opportunities for the community of Pagilaran to participate in enlivening tourism activities, which are trading, participating in tourism events such as cultural festivals, art performances, and become direct tourism actors at ODTW (Tourism Attractions Objects) owned by Pagilaran.

Educational Dimension on the potential of Pagilaran Tea Plantation is that Pagilaran Agrotourism becomes a vehicle, resource, and laboratory to increase knowledge regarding agricultural, plantation, and economics sciences related to export commodities. So far, Pagilaran tea plantation agrotourism accepts students to conduct PKL (Field Work Practice) activities which have been carried out by students from the Faculty of Agriculture in Universities in Indonesia. In the student practice activities, there is a transfer of knowledge between academics and practitioners. They share knowledge and science related to the tea commodity. The management principle of Pagilaran Company is one of them as the Tri Dharma of Higher Education is realized by the existence of educational and research activities of students, lecturers, and researchers. One of the researchers who is interested in the Pagilaran tea plantation is a researcher from Japan who is currently conducting research in Pagilarah tea plantations. Related to Education, PT. Pagilaran also provides facilities in the form of a gamelan set to one of the schools in Pagilaran, namely SD Negeri Keteleng 1 as a culture-based school. The Gamelan is a form of Community Service to Educational Institutions to be used as a medium for learning arts and culture and attractions for the activities of Agrotourism in the Pagilaran tea plantation. A proud achievement in the Educational dimension is that two elementary school teachers in the art field created a tea picking dance that has been performed to tourists, the dancers are elementary school students in Keteleng Village, Pagilaran.

Thus, Pagilaran Tea Plantation Agrotourism potentially can be mapped to realize sustainable tourism.

The statement from SL (Informant 2) explained that:

"Pagilaran Company had a set of gamelan and it was given to SD Negeri Keteleng 1, Blado to be used as learning media and can be used for art performances for visitors or tourists, two art teachers from Pagilaran also succeeded in creating a tea picking dance that has often been performed for tourists danced by elementary school students in Keteleng Village, Pagilaran (R2)".

The characteristic of Pagilaran which has several business concentrations, one of which is Agrotourism, makes Tea plantations come alive and can provide livelihoods for the wider community. Strategic policies are needed to optimize the potential of plantations to be made into environmentalbased agrotourism. Pagilaran Agrotourism is a tourism icon that supports Sustainable Development. The implementation of ecotourism with integration into edutourism makes Agrotourism has the potential to be continuously developed and become an asset for the tourism sector in Indonesia and the world. Sustainable tourism requires medium and long-term plannings defined using the practice of benchmarking aimed at increasing competitiveness [28].

\section{CONCLUSION}

Sustainable development can be realized with tourism sector instruments that apply the principles of sustainability. Agrotourism is a part of tourism that optimizes the natural and social environment to be used to increase knowledge and insight about ecology, culture, education, and aims for the welfare of the community. Pagilaran Tea Plantation Agrotourism has extraordinary potential and uniqueness. Agrotourism is one of the core businesses managed by the Pagilaran Tea Plantation Company. In its management principle, Pagilaran Tea Plantation Agrotourism adopts corporate principles, namely the Tri Dharma of Higher Education and self-supporting. This is due to managerially the 
company is under Gadjah Mada University. The Management Model is by utilizing Pagilaran tea plantations and tea factories for education, tourism with the concept of family and institutional tourism, and supporting edutourism activities.

Pentahelix's Synergy in tourism management is also applied by Pagilaran Tea Plantation Agrotourism with real collaboration involving ABCGM elements (Academic, Business, Community, Government, Media). Sustainability Tourism Model in Pagilaran Tea Plantation Agrotourism has economic, environmental, social, and educational dimensions. This sustainable tourism model is an innovation, unique, and novelty that is owned by Plantation Agrotourism Pagilaran Tea because it has management principles based on the Tri Dharma of Higher Education (Education, Research, and Community Service). The emphasis on tourism for Education is manifested in tour packages offered by promoting educational elements regarding tea plantations, tea commodities, and environmental conservation. Among the tour packages that support elements of Sustainable tourism are tea walking, tea factory, camping and outbound areas of tea plantations, chrysanthemum cultivation, and performances of tea picking dance art.

Sustainable tourism implemented by Pagilaran Tea Plantation Agrotourism has the potential to increase income or turnover for both the company and the surrounding community. The involvement of the community of tourism activists, namely Pokdarwis (Tourism Awareness Group) "Agrobinangkit" makes the existence of Pagilaran Agrotourism participate in empowering local communities so that the social dimension as an element of sustainable tourism is proven to be applied to Agrotourism. Knowledge and insight about tea commodities and how to keep tea plants productive are the efforts and commitments of Pagilaran tea plantations to implement environmental conservation through Pagilaran Agrotourism. Tea plantation agrotourism strongly supports the element of Education by promoting the transfer of knowledge and information about tea plants, tea cultivation, and nature conservation efforts. The uniqueness of the Pagilaran Tea Plantation Agrotourism is the unification of cultural and educational elements with the company providing gamelan facilities to the Primary School in Pagilaran to be used in cultural art performances and Elementary School teachers succeeded in creating the tea picking dance as a supporter for the attraction of Agrotourism to be able to always committed to applying the principles of sustainable tourism.

\section{ACKNOWLEDGMENTS}

This research was supported by funding from the Ministry of Education, Culture, Research, and Technology. Our gratitude to Pagilaran Tea Plantation Company and Postgraduate of Semarang State University.

\section{REFERENCES}

[1] Annex, I. (1992). Report of the United Nations conference on environment and development. Rio de Janeiro (3-14 June 1992) A/CONF.

[2] Desa, U.N. (2016). Transforming Our World: The 2030 Agenda for Sustainable Development. https://doi.org/10.1891/9780826190123.ap02

[3] Nguyen, T.Q.T., Young, T., Johnson, P., Wearing, S.
(2019). Conceptualising networks in sustainable tourism development. Tourism Management Perspectives, 32: 100575. https://doi.org/10.1016/j.tmp.2019.100575

[4] Motala, S., Ngandu, S., Mti, S., et al. (2015). Millennium development goals: Country report 2015.

[5] Fauzia, I.Y. (2016). Urgensi Implementasi Green Economy Perspektif Pendekatan Dharuriyah Dalam Maqashid Al-Shariah. J. Ekon. dan Bisnis Islam, 2(1): 87-104. http://dx.doi.org/10.20473/jebis.v2i1.1503

[6] Asj'ari, F.M.S. (2018). Green economy dalam mendukung millennium development goals (MDGs). Prosiding Conference on Economic \& Business Adi Buana University of Surabaya"Budaya Bisnis Berbasis Ekonomi Hijau di Era Industri 4.0”. https://ceba.unipasby.ac.id/wpcontent/uploads/2018/09/CEBA1-19-UNIPAFACHRUDY.pdf.

[7] D’Alessandro, F. (2016). Green Building for a Green Tourism. A new model of eco-friendly agritourism. Agriculture and Agricultural Science Procedia, 8: 201210. https://doi.org/10.1016/j.aaspro.2016.02.094

[8] Lin, C.L. (2019). The analysis of sustainable development strategies for industrial tourism based on IOA-NRM approach. Journal of Cleaner Production, 241: 118281. https://doi.org/10.1016/j.jclepro.2019.118281

[9] Sonny Keraf, A. (2010). Etika Lingkungan Hidup. Jakarta:

Kompas. https://books.google.co.id/books?id=gW6qG0DQ2_cC $\&$ printsec $=$ frontcover \&hl $=\mathrm{id}$

[10] Toomey, A.H., Knight, A.T., Barlow, J. (2017). Navigating the space between research and implementation in conservation. Conservation Letters, 10(5): 619-625. https://doi.org/10.1111/conl.12315

[11] Loizou, E., Karelakis, C., Galanopoulos, K., Mattas, K. (2019). The role of agriculture as a development tool for a regional economy. Agricultural Systems, 173: 482-490. https://doi.org/10.1016/j.agsy.2019.04.002

[12] Gunadi, R. (2020). Perkebunan di Tanah Koloni. KAGAMA Ngeteh Merdeka: Memerdekakan Teh Indonesia Sabtu 19 September 2020. Yogyakarta, 2020. https://kagama.id/menggelar-webinar-membahas-tehsebagai-wujud-kepedulian-kagama-id-terhadapkemerdekaan-teh-indonesia/.

[13] Prajanti, S.D.W. (2014). Strategy for controlling agricultural land conversion of paddy by using analytical hierarchy process in Central Java. Management of Environmental Quality: An International Journal, 25(5): 631-647. https://doi.org/10.1108/MEQ-07-2013-0080

[14] Yuliando, H., Erma, K.N., Cahyo, S.A., Supartono, W. (2015). The strengthening factors of tea farmer cooperative: Case of Indonesian tea industry. Agriculture and Agricultural Science Procedia, 3: 143-148. https://doi.org/10.1016/j.aaspro.2015.01.028

[15] Sanusi, A. (2020). Memerdekakan Teh Indonesia. KAGAMA Ngeteh Merdeka: Memerdekakan Teh Indonesia Sabtu 19 September 2020. Yogyakarta. https://kagama.id/menggelar-webinar-membahas-tehsebagai-wujud-kepedulian-kagama-id-terhadapkemerdekaan-teh-indonesia/.

[16] Ghani, M.A. (2021). Peran dan Kontribusi Perkebunan Sumatera Timur Dari Masa ke Masa. Disampaikan pada Seminar Daring tentang Perkebunan di Indonesia 8 April 2021. Medan. http://ptpn2.com/wpcontent/uploads/2021/06/Jejak-Planters-di-Tanah- 
Deli_.pdf.

[17] Barbieri, C., Xu, S., Gil-Arroyo, C., Rich, S.R. (2016). Agritourism, farm visit, or...? A branding assessment for recreation on farms. Journal of Travel Research, 55(8): 1094-1108. https://doi.org/10.1177/0047287515605930

[18] Ardika, I.G. (2018). Kepariwisataan Berkelanjutan; Rintis Jalan Lewat Komunitas. 2018. https://gerai.kompas.id/belanja/buku/penerbit-bukukompas/kepariwisataan-berkelanjutan/.

[19] BPS. (2019). Statistik Wisatawan Nusantara. https://www.bps.go.id/publication/2020/06/26/ea3ab267 5715d36cecb374e6/statistik-wisatawan-nusantara2019.html.

[20] Yoeti, O.A. (2010). Pengantar Ilmu Pariwisata Edisi Revisi. Bandung: Angkasa https://www.google.co.id/books/edition/Ekonomi_pariw isata/XJDn_EfA1woC?hl=id\&gbpv $=1 \& \mathrm{dq}=\mathrm{O} .+\mathrm{A},+$ Yoet $\mathrm{i},+$ Pengantar+Ilmu+Pariwisata+Edisi+Revisi.+Bandung :+Angkasa,+2010.\&printsec $=$ frontcover.

[21] Astuti, M.T. (2014). Potensi agrowisata dalam meningkatkan pengembangan pariwisata. Jurnal Destinasi Pariwisata, 1(17): 51-57.

[22] Matteucci, X., Gnoth, J. (2017). Elaborating on grounded theory in tourism research. Annals of Tourism Research, 65: 49-59. https://doi.org/10.1016/j.annals.2017.05.003

[23] Gde Pitana, d.P.G.G.I. (2005). Sosiologi Pariwisata. Yogyakarta: Andi Offset.

[24] James J. Spillane, Pariwisata Indonesia; Siasat Ekonomi dan Rekayasa Kebudayaan. Yogyakarta: Kanisius, 1994. https://books.google.co.id/books/about/Pariwisata_Indo nesia.html?id=jrCAAAAAMAAJ\&redir_esc $=y$.

[25] Kim, D., Perdue, R.R. (2011). The influence of image on destination attractiveness. Journal of Travel \& Tourism Marketing, 28(3): 225-239. https://doi.org/10.1080/10548408.2011.562850

[26] Cini, F., Passafaro, P. (2019). Youth and ecotourism: A qualitative exploration. Tourism and Hospitality Research, 19(1): 126-131. https://doi.org/10.1177/1467358417704887

[27] Therkelsen, A. (2003). Imagining places: Image formation of tourists and its consequences for destination promotion. Scandinavian Journal of Hospitality and Tourism, 3(2): 134-150 https://doi.org/10.1080/15022250310003105

[28] Lozano-Oyola, M., Blancas, F.J., Gonzalez, M., Caballero, R. (2019). Sustainable tourism tags to reward destination management. Journal of Environmental Management, 250: 109458 https://doi.org/10.1016/j.jenvman.2019.109458

[29] Nugroho, I. (2015). Ecotourism and Sustainable Development. Yogyakarta: Student Library. https://widyagama.ac.id/iwan-nugroho/wpcontent/uploads/2013/06/buku-ekowisata.pdf.

[30] Yuan Pan, S., Gao, M., Kim, H., Shah, K.J., Lu Pei, S., Chi Chiang, P. (2018). Advance and challenges in sustainable tourism towards a green economy. Science of the Environment, 635: 452-469. https://doi.org/10.1016/j.scitotenv.2018.04.134

[31] Srisomyong, N., Meyer, D. (2015). Political economy of agritourism initiatives in Thailand. Journal of Rural Studies, 41: 95-108. https://doi.org/10.1016/j.jrurstud.2015.07.007

[32] Ocampo, L., Ebisa, J.A., Ombe, J., Escoto, M.G. (2018). Sustainable ecotourism indicators with fuzzy Delphi
method-A Philippine perspective. Ecological Indicators, 93: 874-888.

https://doi.org/10.1016/j.ecolind.2018.05.060

[33] Baral, N. (2015). Assessing the temporal stability of the ecotourism evaluation scale: Testing the role and value of replication studies as a reliable management tool. Journal of Sustainable Tourism, 23(2): 280-293. https://doi.org/10.1080/09669582.2014.953541

[34] Buckley, R. (2011). Tourism and environment. Annual Review of Environment and Resources, 36: 397-416. https://doi.org/10.1146/annurev-environ-041210132637

[35] Cárdenas, D.A., Byrd, E.T., Duffy, L.N. (2015). An exploratory study of community awareness of impacts and agreement to sustainable tourism development principles. Tourism and Hospitality Research, 15(4): 254-266. https://doi.org/10.1177/1467358415580359

[36] Emirbayer, M., Goodwin, J. (1994). Network analysis, culture, and the problem of agency. American Journal of Sociology, 99(6):

$1411-1454$ https://doi.org/10.1016/j.tmp.2017.11.017

[37] Hsu, C.Y., Chen, M.Y., Nyaupane, G.P., Lin, S.H. (2020). Measuring sustainable tourism attitude scale (SUS-TAS) in an Eastern island context. Tourism Management Perspectives, 33: 100617. https://doi.org/10.1016/j.tmp.2019.100617

[38] Prajanti, S.D.W., Soesilowati, E. (2013). Evaluation on benefits and development of Information and Communication Technology (ICT) to improve the performance of agricultural extension in Central Java. International Journal of Organizational Innovation (Online), 6(2): 243-253.

[39] Guo, Y., Jiang, J., Li, S. (2019). A sustainable tourism policy research review. Sustainability, 11(11): 3187. https://doi.org/10.3390/su11113187

[40] Prajanti, S.D.W., Utami, S. (2019). Capacity building for agricultural extensionists: a case from Indonesia. International Journal of Business and Society, 20(2): 691-708.

[41] Hamzah, A. (2012). Socio-economic impact potential of agro tourism activities on Desa Wawasan Nelayan community living in Peninsular Malaysia. African Journal of Agricultural Research, 7(32): 4581-4588. https://doi.org/10.5897/ajar11.295

[42] Swastika, I.P.D., Dewi, M.K.S.B.M.H.U. (2017). Analisis pengembangan agrowisata untuk kesejahteraan masyarakat di kecamatan petang, kabupaten badung. EJurnal Ekonomi dan Bisnis Universitas Udayana, 6(12): 4103-4136. https://doi.org/10.24843/EEB.2017.v06.i12.p03

[43] Dans, E.P., González, P.A. (2019). Sustainable tourism and social value at World Heritage Sites: Towards a conservation plan for Altamira, Spain. Annals of Tourism Research, 74: 68-80. https://doi.org/10.1016/j.annals.2018.10.011

[44] Creswell, J.W., Creswell, J.D. (2017). Research design: Qualitative, quantitative, and mixed methods approaches. Sage publications.

[45] Putri, S.S.P.Y., Purwani, O., Nugroho, R. (2020). Penerapan Teori the Tourist Gaze Pada Agrowisata Teh Kemuning di Kabupaten Karanganyar Jawa Tengah. Senthongjurnal ilm. Mhs. Arsit., 3(1): 242-251. https://jurnal.ft.uns.ac.id/index.php/senthong/article/vie w/1103. 